\title{
Review on Middle East Respiratory Syndrome
}

\author{
Berihun Dires $^{1 *}$, Fufa Dawo ${ }^{2}$ \\ ${ }^{1}$ Department of Animal Science, Gambella University, Gambella, Ethiopia \\ ${ }^{2}$ Addis Ababa University College of Agriculture and Veterinary Medicine, Bishoftu, Ethiopia \\ Email: "berihundires@yahoo.com
}

Received 19 November 2015; accepted 4 December 2015; published 9 December 2015

Copyright (C) 2015 by authors and OALib.

This work is licensed under the Creative Commons Attribution International License (CC BY). http://creativecommons.org/licenses/by/4.0/

(c) (i) Open Access

\begin{abstract}
Middle East respiratory syndrome (MERS) is a respiratory disease caused by a newly recognized Middle East respiratory syndrome-coronavirus (MERS-CoV). It is an RNA virus, with positive sense, single-stranded RNA genomes of 30.1 kilobase $(\mathrm{kb})$. Based on its genome sequence, the virus has been classified within lineage $2 \mathrm{C}$ of the genus Betacoronavirus. The disease was first reported in 2012 and is now spreading to different parts of the world. Dromedary camels (Camelus dromedarius) are suggested to be the primary animal host that acts as a source of human infection by MERS-CoV. Most patients with MERS-CoV infection have been severely ill with pneumonia and acute respiratory distress syndrome, and some showed acute kidney injury. There is no specific vaccine or treatment for MERS-CoV infection other than supportive treatment. Collection of the specimens from lower respiratory tract, upper respiratory tract and serum for isolation and characterization of the virus using different techniques such as real time reverse transcription polymerase chain reaction (RT-rt PCR) and serological tests are recommended. Up to June 18, 2015, 498 of the 1327 cases have died with case fatality rate of $\sim 38 \%$ [1]. This emerging infectious disease is a threat to human health. Proper infection-control measures including contact and airborne precautions should be implemented while managing patients with suspected MERS-CoV infection.
\end{abstract}

\section{Keywords}

Middle East Respiaratory Syndrome-Coronavirus, Middle East Respiratory Syndrome, Betacoronavirus, Real Time Reverse Transcription PCR, Serology

Subject Areas: Infectious Diseases

\section{Introduction}

Middle East respiratory syndrome (MERS) is a respiratory disease caused by a newly recognized coronavirus,

${ }^{*}$ Corresponding author. 
MERS-CoV. It was first reported in 2012 in Saudi Arabia and is thus far linked to countries in or near the Arabian Peninsula (United Arab Emirates (UAE), Qatar, Oman, Jordan, Kuwait, Yemen, and Lebanon) [2]. This novel coronavirus, initially termed human coronavirus-EMC (for Erasmus Medical Center) virus, has been named the MERS-CoV by the International Coronavirus Study Group of the International Committee on Taxonomy of Viruses (ICTV) [3]. It is a member of a new species within the order: Nidovirales, Family: Coronaviridae, Subfamily: Coronavirinae, Genus: Betacoronavirus [4]. Based on its genome sequence, the virus has been classified within lineage $2 \mathrm{C}$ of the genus Betacoronavirus. MERS-CoV is closely related to Tylonycteris bat CoV HKU4 and Pipistrellus bat CoV HKU5, the two prototype species in lineage C Betacoronavirus [5].

The genome of MERS-CoV includes 30,100 nucleotides and contains 10 predicted open reading frames (ORF1a, ORF1b, Spike (s), ORF3, ORF4a, ORF4b, ORF5, Envelope (E), Membrane (M), and Nucleoprotein (N)) [4]. A functional receptor of MERS-CoV that helps to establish infection is dipeptidyl peptidase 4 (DPP-4) from both human and bat [6]. This receptor has 231-residues region in the spike (S) protein of MERS-CoV, a domain different from the receptor-binding site of other Betacoronaviruses [7]. MERS is typically characterized by cough, fever, and shortness of breath [2]. Potentially at-risk individuals include care givers and close contacts of people with suspected or confirmed MERS-CoV infection. Transmission has occurred via close contact with infected person and camels, including from patients to healthcare personnel [8].

Collection of multiple specimens from different sites at various times following the onset of symptoms is recommended. Infection-control measures should be used during collection using approved equipment and methods. Specimens should be handled, stored, and shipped following appropriate protocols [9]. MERS-CoV is primarily diagnosed using a RT-rtPCR assay and serological tests such as western blot analysis, enzyme linked immunosorbent assay (ELISA), indirect immunoflourescence assay (IFA) and micro-neutralization can help in isolation and characterization of the virus [10]-[12]. No vaccine currently exists for MERS, and no specific treatment has also been recommended. Management of the disease is currently supportive treatment [8].

All cases reported outside of the Middle East have had a recent travel history to the Middle East or contact with a case travelled from the Middle East. A WHO statement in April 2014 indicated that 75\% of MERS cases reported recently appear to be secondary cases (acquired from another infected person) [13]. Travelers who have recently visited countries in or near the Arabian Peninsula are advised to contact their healthcare provider if they develop MERS symptoms within 14 days of travel. Individuals who have been in recent contact with a symptomatic person who has recently traveled to the Arabian Peninsula should also be evaluated for MERS-CoV infection. Contact and airborne precautions are recommended for management of hospitalized patients with known or suspected MERS-CoV infection [3] [9].

Therefore, the objectives of this paper are:

- To review the general feature of MERS and,

- To describe isolation and characterization techniques used for MERS-CoV.

\section{Middle East Respiratory Syndrome: Coronavirus Infection}

\subsection{Etiology of MERS}

Middle East respiratory syndrome is caused by Coronaviruses. Coronaviruses are classified into 4 genera: Alphacoronavirus, Betacoronavirus, Gammacoronavirus and Deltacoronavirus [14] [15]. MERS-CoV is a newly discovered Betacoronavirus lineage 2C that was first reported in 2012 [16]. Coronaviruses are largest of all RNA viruses, with positive single-stranded RNA genomes of 26 - $32 \mathrm{~kb}$ [14] [15].

\subsection{Epidemiology of MERS}

Emerging infectious diseases are a constant threat to human health. Of specific and current concern is MERS caused by coranavirus which spreading globally and causing many mortalities. In April 2012, the MERS-CoV emerged in Saudi Arabia and then the disease was reported from countries found in Arabian Peninsula, Europe, USA, and Asian countries like China and South Korea [1] [15].

\subsubsection{Geographical Distribution}

Since April 2012, more than 1300 laboratory-confirmed human infections with MERS-CoV have been reported to the World Health Organization (WHO), occurring in several countries in the Arabian Peninsula, including 
Jordan, Kuwait, Lebanon, Oman, Qatar, Saudi Arabia, the United Arab Emirates, and Yemen with the majority of cases occurred in Saudi Arabia (Figure 1). A limited number of cases have also been reported from Algeria, Austria, China, Egypt, France, Germany, Greece, Iran, Italy, Malaysia, the Netherlands, the Philippines, South Korea, Thailand, Tunisia, Turkey, the United Kingdom, and the United States. In the European and Asian countries as well as in Algeria, Egypt, Tunisia, and the United States, patients developed illness after returning from the Arabian Peninsula (Figure 1). In the United Kingdom, France, Italy, and Tunisia, limited human-to-human transmission occurred among close contacts of the index cases. The median age is 48 years (range 9 months to 94 years) and 64 percent of cases reported to be males [17] [18].

MERS outbreak is ongoing in South Korea since May 2015; the index case was a man who had recently traveled to Bahrain, the United Arab Emirates, Saudi Arabia, and Qatar. As of mid-June 2015, more than 160 secondary cases have been reported among household and hospital contacts of which 16 deaths were reported. All of the cases outside of the Middle East have had a direct or indirect connection to the Middle East. Of the 1327 cases, 498 have died with case fatality rate of 38\% [1] (Table 1).

\subsubsection{Possible Source and Transmission}

Dipeptidyl peptidase 4 (DPP4; also known as CD26), which is present on the surfaces of human non ciliated bronchial epithelial cells, is a functional receptor for MERS-CoV (Raj et al., 2013). The specific transmission mechanisms between humans and the possible source animals are unknown. Human-to-human transmission has been demonstrated, but the chains of transmission have not been self-sustained [8] [16].

Dromedary camels are suggested to be the primary animal host for MERS-CoV. The strongest evidence of camel-to-human transmission of MERS-CoV comes from a study in Saudi Arabia in which MERS-CoV was isolated from a man with fatal infection and from one of his camels. Full-genome sequencing of MERS-CoV viruses from the man and his camels demonstrated that the viruses isolated from the man and his camel were identical. The man had applied a topical medicine to the nose of one of the ill camels seven days before he became ill; the results suggest that MERS-CoV can infect dromedary camels and can be transmitted from them to humans by close contact [20].

Serologic studies have also suggested that camels are an important source of MERS-CoV: Of 203 serum samples from dromedary camels in various regions of Saudi Arabia collected in 2013, 150 (74 percent) had antibodies to MERS-CoV by enzyme-linked immunosorbent assay. The rate of sero-positivity was higher in adult than juvenile camels ( $>95$ percent among camels $>2$ years of age versus 55 percent in camels $\leq 2$ years of age). Almost all adult camels ( $>90$ percent) from countries in the Arabian Peninsula, Jordan, Egypt, Nigeria, and Ethiopia show antibody evidence of prior MERS-CoV infection; adult camels in other countries of the region (Kenya, Tunisia, Spain, Canary Islands) are also MERS-CoV antibody positive but at a lower prevalence [21]-[23] (Figure 1).

Table 1. Cases classified according to country where infection was acquired.

\begin{tabular}{ccc}
\hline Country & Cases & Deaths \\
Saudi Arabia & 1048 & 454 \\
South Korea & 150 & 16 \\
United Arab Emirates (UAE) & 75 & 8 \\
Jordan & 17 & 6 \\
Qatar & 15 & 6 \\
Oman & 6 & 3 \\
Iran & 6 & 2 \\
Kuwait & 3 & 1 \\
Tunisia & 2 & 0 \\
United Kingdom & 2 & 1 \\
Yemen & 1 & 1 \\
France & 1 & 0 \\
Lebanon & 1 & 0 \\
TOTAL & 1,327 & 498 \\
\hline
\end{tabular}

Source: http://www.wpro.who.int/outbreaks_emergencies/wpro_coronavirus/en/ (accessed on June 18, 2015). 


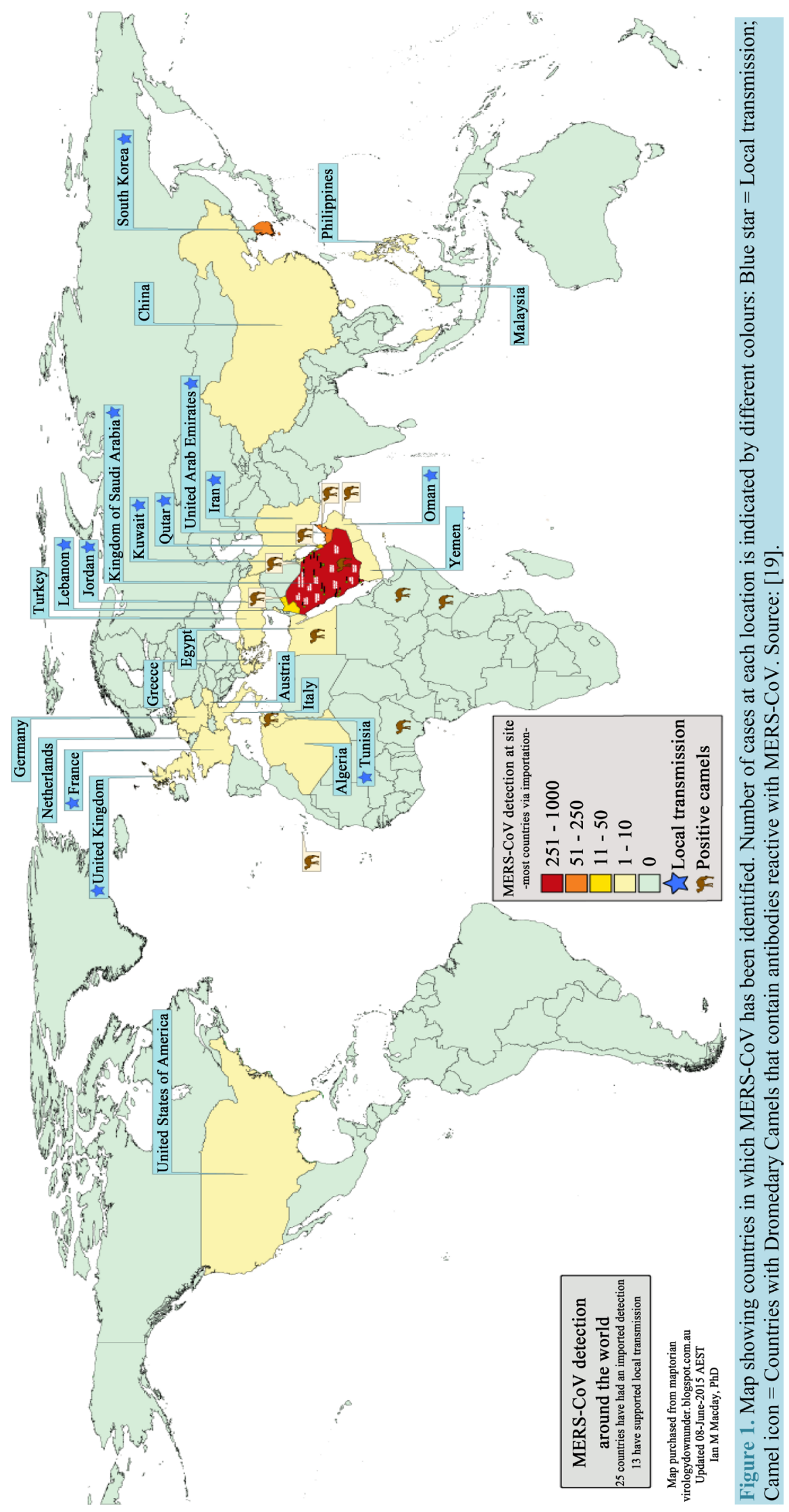


Coronavirus RNA sequences are also found in bat fecal samples and that some of these sequences are closely related to MERS-CoV sequences [24]. MERS-CoV grows readily in bat-derived cell lines. Although bats might be a reservoir of MERS-CoV, it is unlikely that they are the immediate source for most human cases because human contact with bats is uncommon [25].

Human to human transmission accounted for $75 \%$ of MERS cases reported due to secondary cases (acquired from another infected person). Other possible modes of MERS transmission to humans include droplet of patients and contact transmission [13] [26]. Even though, it is unclear how the virus is transmitted from camels to humans, the WHO advises avoiding contact with camels and to eat only fully cooked camel meat, pasteurized camel milk, and to avoid drinking camel urine [27]. A speculative model of how humans, camels and bats may interact to acquire and spread MERS-CoV is given by [19] (Figure 2).

\subsection{Clinical Sign}

Most patients with MERS-CoV infection have been severely ill with pneumonia and acute respiratory distress syndrome, and some have had acute kidney injury. Many patients have required mechanical ventilation, and some have required extracorporeal membrane oxygenation. Other clinical manifestations that have been reported are gastrointestinal symptoms (anorexia, nausea, vomiting, abdominal pain, diarrhea), pericarditis, and disseminated intravascular coagulation [28].

The clinical findings observed among 47 patients with MERS-CoV infection in Saudi Arabia include; fever $\left(>38^{\circ} \mathrm{C}\right) 98 \%$, fever with chills or rigors $87 \%$, cough $83 \%$, shortness of breath $72 \%$, hemoptysis $17 \%$, sore throat $21 \%$, myalgias $32 \%$, diarrhea $26 \%$, vomiting $21 \%$, abdominal pain $17 \%$, abnormal chest radiograph $100 \%$ (Figure 3). Of these 47 patients, $89 \%$ required intensive care and $72 \%$ required mechanical ventilation. The

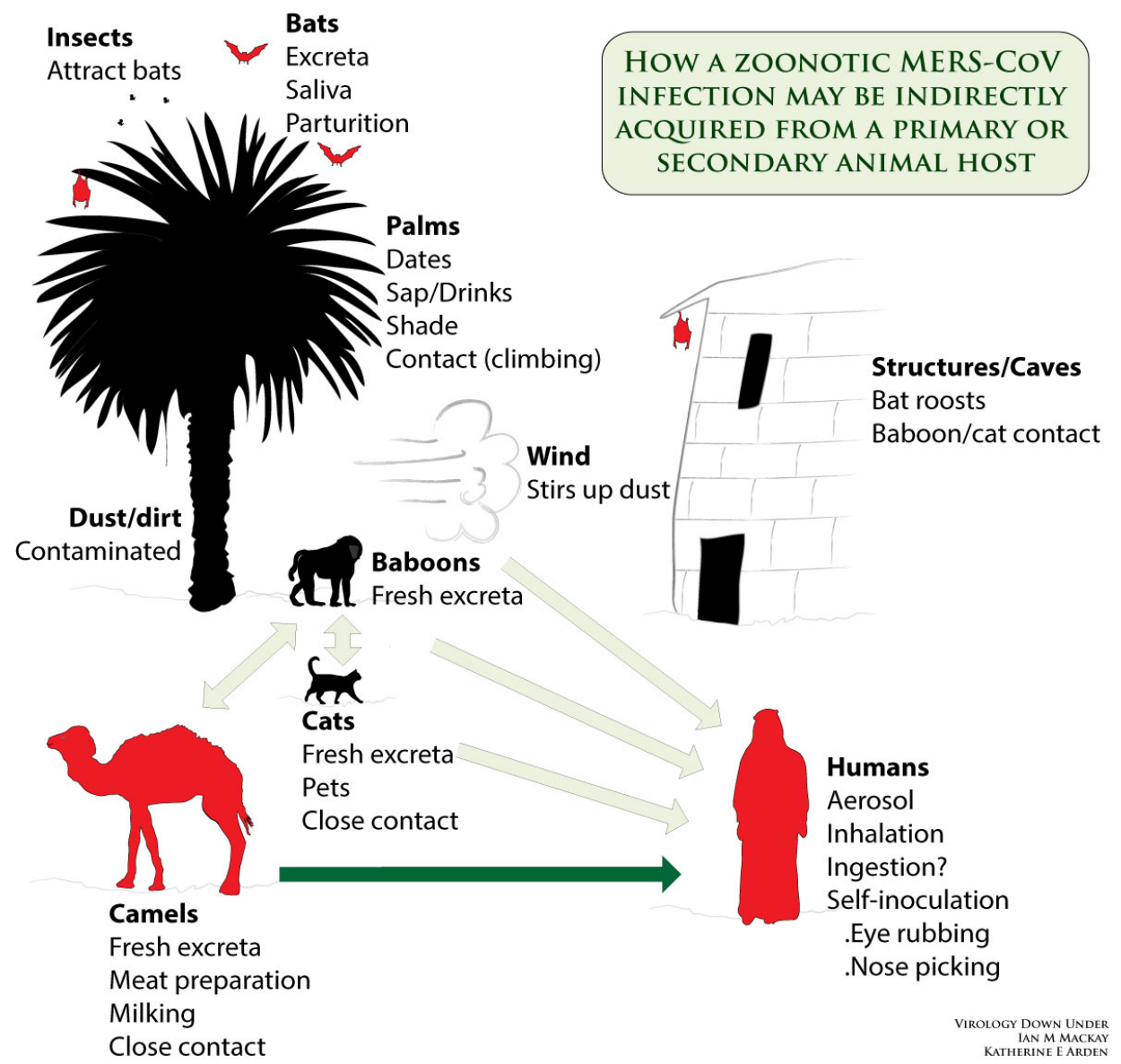

Figure 2. A speculative model of how humans, camels and bats may interact to acquire and spread MERS-CoV. Highlighted in red are MERS-CoV virus/RNA and/or antibody-positive hosts. Source: [19]. 


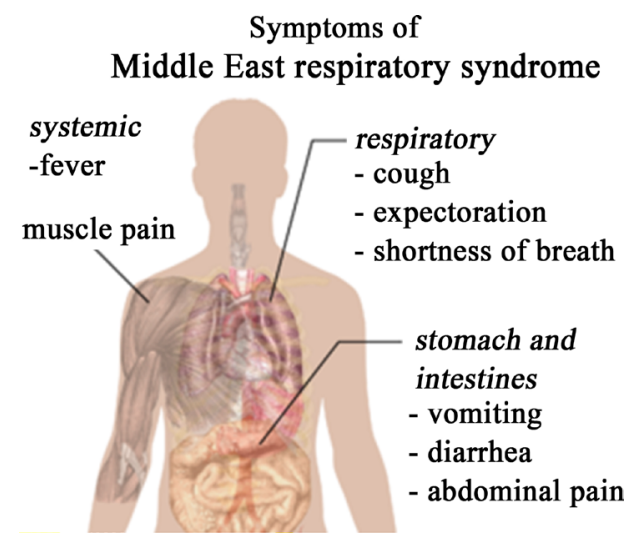

Figure 3. Symptoms of MERS. Source: [30].

median time from presentation for medical care to mechanical ventilation was 7 days (range 3 to 11 days) and to death was 14 days (range 5 to 36 days) [29].

\subsection{Isolation and Characterization of MERS-CoV}

\subsubsection{Sample Collection}

Collection of specimens from lower respiratory tract (broncheo-alveolar lavage, tracheal aspirate, pleural fluid, sputum), upper respiratory tract (nasopharyngeal swab and oropharyngeal swab, nasopharyngeal wash/aspirate or nasal aspirate) and serum are required for diagnosis [9].

\subsubsection{Virus Propagation}

Vero A66 and Human hepatocellular carcinoma cell line 7 (Huh-7 cells) were previously used for growing the virus. MERS-CoV viruses can be recovered from the full-length Complementary DNA (cDNA) clone, using susceptible Vero A66 and Huh-7 cells, with titers of around $10^{6}$ plaque-forming unit/ml (p.f.u./ml) at 72 h post transfection (h.p.t.). The recovered viruses can be cloned by three rounds of plaque purification, and their phenotypic and genotypic properties can be determined. MERS-CoV rescued from both cell lines induce a clear cytopathic effect (CPE), characterized by the induction of cell fusion, which was more apparent in Huh-7 cells [31]. In both cell lines, viral mRNAs could be readily detected at $7 \mathrm{~h}$ post-infection (p.i.) and reached maximum levels around 13 h p.i. Viral RNA levels remained more or less constant until 24 h p.i. in Vero cells, whereas the amount isolated from Huh7 cells declined due to the more rapid development of cytopathology in this cell line between 13 and 24 h p.i. After the peak of viral RNA accumulation had been reached, the titre of virus released from MERS-CoV infected Vero cells increased steadily from $\sim 5 \times 10^{5}$ to $\sim 5 \times 10^{7}$ p.f.u./ml. The bulk of the viral progeny are released significantly earlier from Huh7 cells, although the final titre at $24 \mathrm{~h}$ p.i. are comparable to that obtained from Vero cells [32].

\subsubsection{Incubation Period}

The incubation period in humans infected with MERS-CoV ranges from 3 to 11 days [33].

\subsubsection{MERS-CoV Genome Structure and Proteins}

Generally, coronaviruses are enveloped RNA viruses that infect and cause disease in a broad array of animals and humans (Figure 4). Virus particles range from 70 to $120 \mathrm{~nm}$ in diameter and are surrounded by characteristic spike-shaped glycoproteins. The viruses contain the largest single-stranded, positive-sense RNA genomes currently known, which range from 26 to nearly $32 \mathrm{~kb}$ in length. All coronaviruses encode strain-specific accessory genes in Open Reading Frames (ORFs) downstream of ORF1 (the replicase-transcriptase), the order of essential structural genes is remarkably well-conserved. All coronaviruses encode the replicase-transcriptase (gene 1), spike, envelope, membrane and nucleocapsid proteins [4]. The $\sim 180 \mathrm{kDa}$ spike glycoprotein mediates hostcell attachment and entry, utilizing virus- and host-specific cell receptors. The receptor-binding domain (RBD) of the spike glycoprotein is poorly conserved among viruses and, as a result, host receptor usage varies between viral genera and species [6]. 


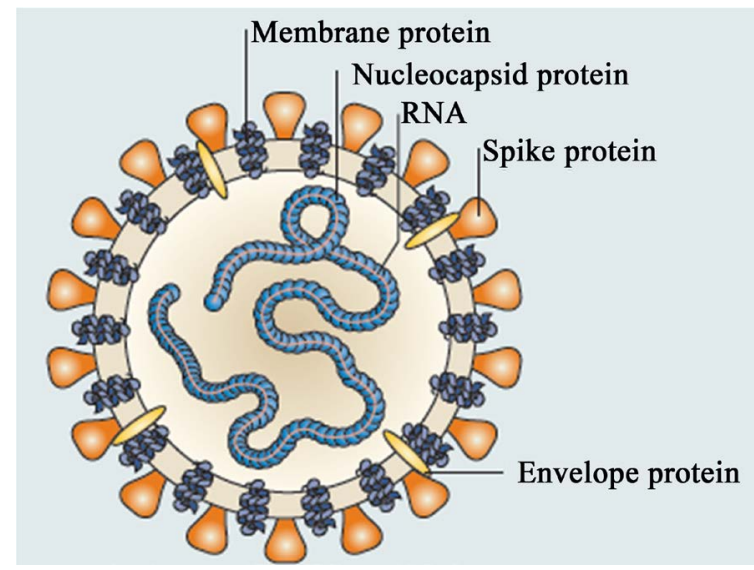

Figure 4. Structure of coronavirus. Source: [35].

The genome of MERS-CoV includes 30,100 nucleotides and contains 10 predicted open reading frames (ORF1a, ORF1b, spike (S), ORF3, ORF4a, ORF4b, ORF5, envelope (E), membrane (M), and nucleocapside (N) [4] [15]. Structural proteins include the S, E, M and N (van Boheemen et al., 2012) (Figure 4). Nonstructural proteins (nsps) include a papain-like protease (PLpro), non structural protein4 (nsp4), transmembrane domains (nsp4, nsp6), a 3C-like protease (3CLpro; nsp5 [34]), an RNA-dependent RNA polymerase (RdRp; nsp12), a helicase (nsp13) and an exonuclease (nsp14) [4].

\subsubsection{Molecular Detection of MERS-CoV Infection}

1) Real time reverse transcription polymerase chain reaction (RT-rtPCR)

MERS-CoV is primarily diagnosed using a RT-rtPCR assay, and the tests for diagnosis using RT-rtPCR are an assay targeting upstream of the E protein gene (upE), assays targeting the open reading frame $1 \mathrm{~b}$ (ORF 1b) and the open reading frame 1a (ORF1a) (Figure 5). The first probe and primer sets for MERS-CoV detection by RT-rtPCR were developed shortly following the first reports of the disease by [10]. The probe and primer sets targeting upstream of the E protein gene (upE), ORF1b, and ORF1a are most widely used targets for MERS $\mathrm{CoV}$ detection. Primers for upE target includes forward (Fwd) (GCAACGCGCGATTCAGTT), upE reverse (Rev) (GCCTCTACACGGGACCCATA), and $200 \mathrm{nM}$ of probe upE-Prb (6 carboxyfluorescein [FAM]) CTC TTCACATAATCGCCCCGAGCTCG 6 carboxy N,N,N,N' tetramethylrhodamine [TAMRA]). Primers for ORF1b includes Fwd (TTCGATGTTGAGGGTGCTCAT), ORF1b Rev (TCACACCAGTTGAAAATCCTA ATTG), and probe ORF1b Prb (6 carboxyfluorescein [FAM]) CCCGTAATGCATGTGGCACCAATGT-6 carboxy N,N,N,N'-tetramethylrhodamine [TAMRA]). The primers for ORF1a include Fwd (CCACTACTCCCA TTTCGTCAG), ORF1a Rev (CAGTATGTGTAGTGCGCATATAAGCA), and probe ORF1a Prb (6 carboxyfluorescein (FAM) TTGCAAATTGGCTTGCCCCCACT-6-carboxy-N,N,N,N'-tetramethylrhodamine (TAMRA)). Thermal cycling involves $55^{\circ} \mathrm{C}$ for 20 minute (min), followed by $95^{\circ} \mathrm{C}$ for $3 \mathrm{~min}$ and then 45 cycles of $95^{\circ} \mathrm{C}$ for 15 seconds (s), $58^{\circ} \mathrm{C}$ for $30 \mathrm{~s}, 72^{\circ} \mathrm{C}$ for $30 \mathrm{~s}[10]$.

Two target sites on the novel coronavirus genome suitable for sequencing using RT-rtPCR assay are the RNA dependent RNA polymerase gene (RdRpSeq assay) and nucleocapsid protein gene ( $\mathrm{N}$ gene) (NSeq assay) (Figure 5), where an insertion/deletion polymorphism might exist among different human coronavirus-Erasmus Erasmus Medical Center (hCoV-EMC) strains. For RNA-dependent RNA polymerase (RdRp) primers includes RdRpSeq-Fwd (TGC TAT WAG TGC TAA GAA TAG RGC; $\mathrm{R}=\mathrm{A} / \mathrm{G}, \mathrm{W}=\mathrm{A} / \mathrm{T}$ ), RdRpSeq-Rev (GCA TWG CNC WGT CAC ACT TAG G; $\mathrm{W}=\mathrm{A} / \mathrm{T}, \mathrm{N}=\mathrm{A} / \mathrm{C} / \mathrm{T} / \mathrm{G}$ ) with Thermal cycling performed at $50^{\circ} \mathrm{C}$ for 20 min, followed by $95^{\circ} \mathrm{C}$ for $3 \mathrm{~min}$ and then 45 cycles of $95^{\circ} \mathrm{C}$ for $15 \mathrm{~s}, 56^{\circ} \mathrm{C}$ for $15 \mathrm{~s}$ and $72^{\circ} \mathrm{C}$ for $30 \mathrm{~s}$, with a terminal elongation step of $72^{\circ} \mathrm{C}$ for 2 min. For RT-rtPCR for sequencing in the $\mathrm{N}$ gene the assay employed the same conditions as the RdRpSeq assay, except that the primer sequences were NSeq-Fwd (CCT TCG GTA CAG TGG AGC CA) and NSeq-Rev (GAT GGG GTT GCC AAA CAC AAA C) for the first round and NSeq-Fwd (TGA CCC AAA GAA TCC CAA CTA C) and NSeq-Rev (the same as in the first round) for the second round. The second round will only performed if no product is visible by agarose gel electrophoresis after the first round [36]. 
The assay for the upE target is considered highly sensitive and is recommended for screening, the ORF1a assay considered of equal sensitivity and the ORF $1 \mathrm{~b}$ assay less sensitive than the ORF1a assay are used for confirmation. Sequencing of RdRp gene and N gene also aid the confirmation [10] [36] [37] (Figure 6). Using RT-rtPCR, viral isolation, and full-genome sequencing that both MERS-CoV-Jeddah-human-1 (accession number KF958702) and MERS-CoV-Jeddah-camel-1 (accession number KF917527) isolates were 100\% identical and contain characteristic mutations compared to other reported sequences, suggesting direct cross-species transmission from the camels to the patient [38].

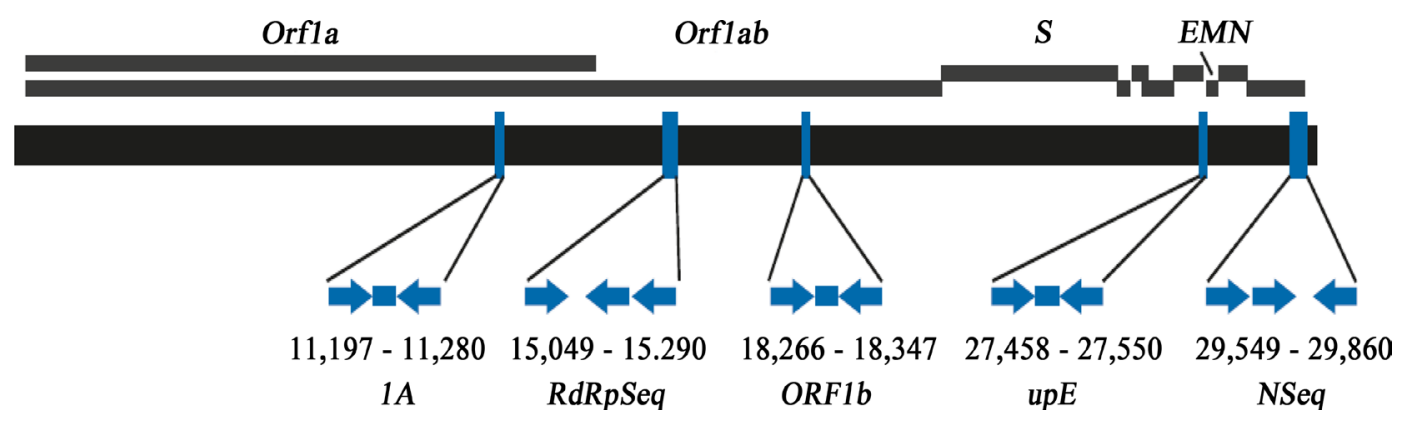

Figure 5. RT-rtPCR target regions for screening, confirmation and sequencing of novel human coronavirus (hCoV-EMC). Source: [36].

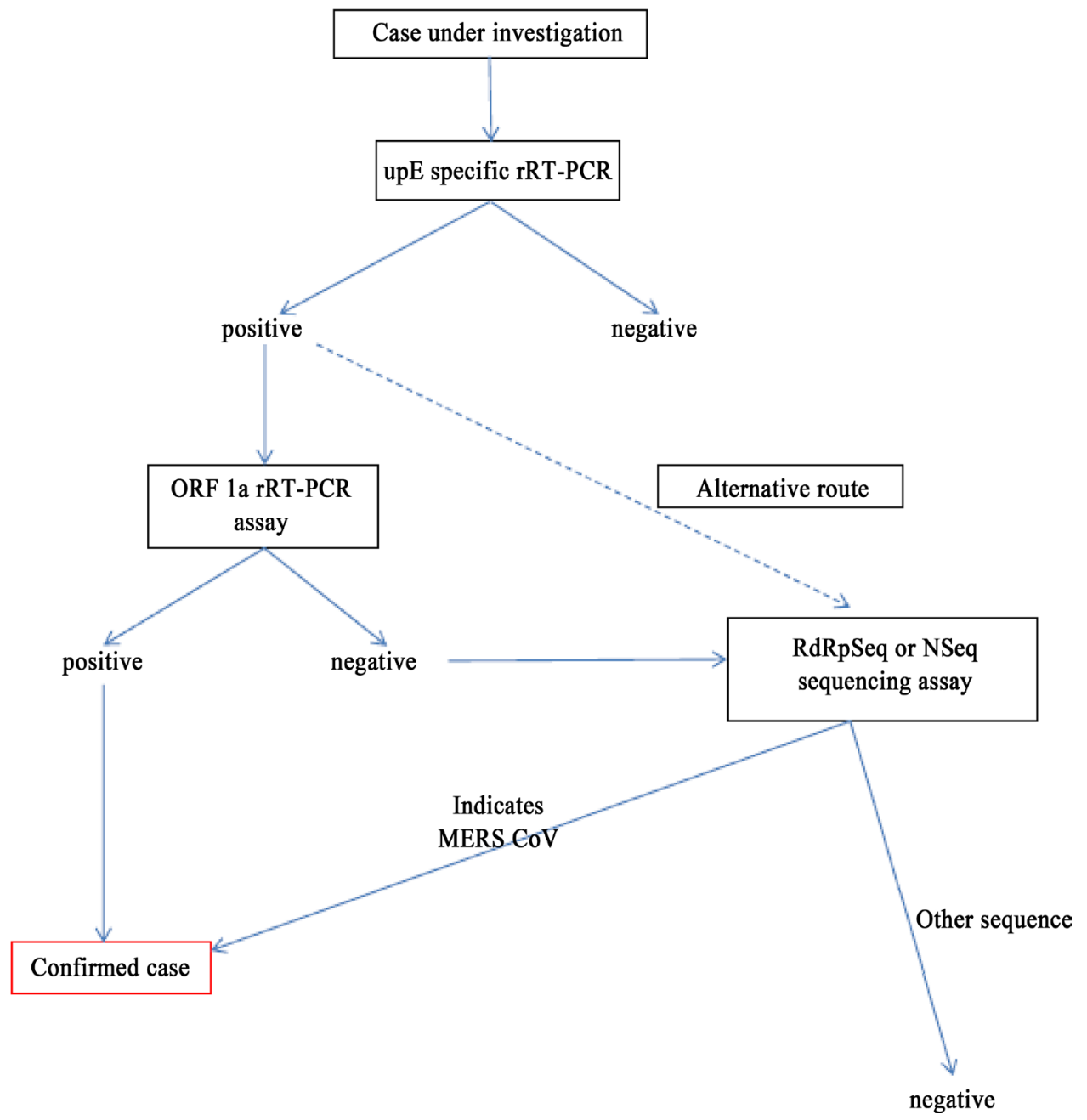

Figure 6. Testing algorithm for cases under investigation for MERS-CoV by RT-rtPCR. Source: [37]. 


\subsubsection{Serological Tests}

The presence of antibodies to MERS-CoV indicates that a person had been previously infected with the virus and developed an immune response. Center for disease control and prevention (CDC) has a two-phase approach for serology testing, using one screening test (ELISA) and two confirmatory tests (IFA, Micronutralization) to detect antibodies to MERS-CoV [11].

1) Enzyme Linked Immunosorbent Assay (ELISA)

Enzyme-linked immunosorbent assay is a screening test used to detect the presence and concentration of specific antibodies that bind to a viral protein. The serum specimens should be collected during the acute stage of the disease and repeated during the convalescence phase ( $>3$ weeks after the initial sample was collected). ELISAs usually produce results within a few hours. If a clinical sample is determined to be antibody-positive by ELISA, CDC then uses the IFA assay and/or microneutralization assay to confirm the positive result [11].

2) Indirect Immunofluorescence Assay (IFA)

Immunofluorescence assay is a confirmatory test in which specific antibodies, if present in the person's blood, attach to virus-infected cells fixed on a glass slide. These attached antibodies are detected by adding a secondary antibody labeled with a compound that makes them glow an apple-green color when viewed under a special microscope. This secondary antibody will bind to any antibodies which are present in the blood and have attached to the virus-infected cells. Like the ELISA results, IFA results can also be obtained in a few hours. If a clinical sample is positive by both ELISA and IFA, the specimen is determined to be positive. If a clinical sample is positive by ELISA but indeterminate or negative by IFA, CDC then performs additional confirmatory testing [11]. This assay may generate false positive results due to the global co-circulation of four human Coronaviruses (hCoV) namely hCoV-NL63, hCoV-OC43, hCoV-229E and hCoV-HKU1. Cross-reactivity to conserved viral proteins limits the use of such whole virus-based IFAs, especially as antibodies against Coronaviruses within a genus are generally known to cross-react [39].

3) Microneutralization Assay

The microneutralization assay is a highly specific confirmatory test used to measure neutralizing antibodies, or antibodies that can neutralize virus. This method is considered the "gold standard" for detection of specific antibodies in serum samples. However, compared with the ELISA and IFA, the microneutralization assay is labor-intensive and time-consuming, requiring at least 5 days before results are available. If a clinical sample is positive by ELISA, indeterminate by IFA, and positive by microneutralization, the specimen is determined to be positive. If a clinical sample is positive by ELISA, indeterminate or negative by IFA and negative by microneutralization, the sample is determined to be negative. Final determination of a positive serology result requires a positive ELISA test and confirmation by IFA or microneutralization assay [11].

4) Western Blot Analysis

For Western blot analysis purified hexa histidine (His) $)_{6}$-tagged nucleoproteins (NPs) of MERS-CoV, are subjected to $12 \%$ Sodium dodecyl sulfate Polyacrylamide gel electrophoresis (SDS-PAGE) and transferred to 0.22 $\mathrm{mm}$ nitrocellulose membranes. The membranes are blocked with $5 \%$ skim milk in Tris-buffered saline and then incubated with mouse anti-MERS-CoV NP immune sera at $37^{\circ} \mathrm{C}$ for $60 \mathrm{~min}$. Antigen-antibody interaction detected with 1:4000 diluted horseradish peroxidase (HRP)-conjugated goat anti-mouse IgG and visualized by 3,3',5,5'-tetramethylbenzidine (TMB) liquid substrates system for membranes [12].

\subsection{Treatment and Prevention Approaches}

Management of MERS-CoV infection is supportive. This includes hydration, antipyretic, analgesics, respiratory support, and antibiotics, if needed, for bacterial super infection. Current treatment is based on previous experience with the Severe Acute Respiratory Syndrome-Coronavirus (SARS-CoV), in vitro studies, and case series. Various agents have been tried, including those that block virus entry, inhibit viral replication, or interfere with host immune response [40]. Monoclonal antibodies that efficiently block the interaction between the MERS$\mathrm{CoV}$ envelope spike glycoprotein and a human protein dipeptidyl peptidase 4 have been developed using a humanized mouse (transgenic mouse). These researchers are now working to move the antibodies into human trials [41]. Based on experience with SARS-CoV, the use of convalescent plasma, hyper-immune globulin, or human monoclonal antibodies that contain neutralizing antibodies may be efficacious and is recommended as first-line treatment when available [40].

CDC recommends that ill individuals who are being evaluated for MERS-CoV infection and do not require 
hospitalization may be cared for and isolated in their home. Healthcare providers should contact their state or local health department to determine whether home isolation or additional measures are indicated because recommendations might be modified as more data become available [2].

The WHO recommends that individual at high risk of severe disease, such as immunocompromised and those with diabetes, chronic lung disease, or preexisting renal failure should take precautions when visiting farms, barn areas, camel pens, or market environments where camels are present [42]. These measures include avoiding contact with camels, practicing good hand hygiene, avoiding drinking raw camel milk or camel urine, avoiding eating camel meat not cooked thoroughly, and avoiding eating food that may be contaminated with animal secretions or products unless they are properly washed, peeled, or cooked. Although, when visiting a farm or barn, general hygiene measures including regular hand washing before and after touching animals and avoiding contact with sick animals, are recommended [13]. Individuals should avoid contact with any camel that has tested positive for MERS-CoV unless wearing a face mask and protective clothing, until subsequent tests have confirmed that the animal is free of virus [42]. Countries outside the affected region should maintain a high level of vigilance, especially countries with large numbers of travelers or guest workers returning from the Middle East [27].

\section{Conclusion}

Middle East respiratory syndrome is caused by Betacoronavirus lineage 2C having the largest genome of all RNA viruses. All cases reported outside of the Middle East have had a recent travel history to the Middle East or contact with a case that had travelled from the Middle East. Using RT-rtPCR, viral isolation and full-genome sequencing of MERS-CoV from human and from camel isolates were identical suggesting direct cross-species transmission from the camels to human. Transmission occurred via close contact with infected persons and camels. MERS-CoV is primarily diagnosed using a real-time RT-PCR assay and serological tests such as western blot analysis, enzyme linked immunosorbent assay, indirect immunoflourescence assay and micro-neutralization can help in diagnosis. As there is no specific vaccine or treatment, management of MERS-CoV infection is by supportive treatment. This emerging infectious disease is a threat to human health.

\section{Recommendations}

The following recommendations are forwarded in order to cope up with this problem.

- Regular hand washing before and after touching camels, wearing a face mask and protective clothing, strict avoidance of contact with camel that has tested positive for MERS-CoV until subsequent tests have confirmed that the animal is free of virus.

- The Health department of the area should be notified immediately if a case of MERS-CoV infection is suspected.

- More than 90\% Camels in Ethiopia are serologically positive (Reusken et al., 2014) which indicates that Ethiopia is under threat of the disease. So, thorough follow up, diagnosis (serology, isolation and identification, and molecular) is required both in humans and animals.

- Extensive efforts are required to speed up the development of an effective therapy and vaccine.

- Camels may play important role in transmission of the virus, and the common practices in pastoral areas of consuming unpasteurized camels' milk and raw meat should be avoided.

\section{References}

[1] World Health Organization (2015) MERS-CoV in the Republic of Korea at a Glance. http://www.wpro.who.int/outbreaks_emergencies/wpro_coronavirus/en

[2] Bialek, S.R., Allen, D., Alvarado-Ramy, F., Arthur, R., Balajee, A., Bell, D., Best, S., Blackmore, C., Breakwell, L., Cannons, A., Brown, C., Cetron, M., Chea, N., Chommanard, C., Cohen, N., Conover, C., Crespo, A., Creviston, J., Curns, A.T., Dahl, R., Dearth, S., DeMaria, A., Echols, F., Erdman, D.D., Feikin, D., Frias, M., Gerber, S.I., Gulati, R., Hale, C., Haynes, L.M., Heberlein-Larson, L., Holton, K., Ijaz, K., Kapoor, M., Kohl, K., Kuhar, D.T., Kumar, A.M., Kundich, M., Lippold, S., Liu, L., Lovchik, J.C., Madoff, L., Martell, S., Matthews, S., Moore, J., Murray, L.R., Onofrey, S., Pallansch, M.A., Pesik, N., Pham, H., Pillai, S., Pontones, P., Pringle, K., Pritchard, S., Rasmussen, S., Richards, S., Sandoval, M., Schneider, E., Schuchat, A., Sheedy, K., Sherin, K., Swerdlow, D.L., Tappero, J.W., Vernon, M.O., Watkins, S. and Watson, J. (2014) First Confirmed Cases of Middle East Respiratory Syndrome Coronavirus (MERS-CoV) Infection in the United States, Updated Information on the Epidemiology of MERS-CoV Infection, and 
Guidance for the Public, Clinicians, and Public Health Authorities. CDC Morbidity and Mortality Weekly Report, 63, 431.

[3] de Groot, R.J., Baker, S.C., Baric, R.S., Brown, C.S., Drosten, C., Enjuanes, L., Fouchier, R.A., Galiano, M., Gorbalenya, A.E., Memish, Z.A., Perlman, S., Poon, L.L., Snijder, E.J., Stephens, G.M., Woo, P.C., Zaki, A.M., Zambon, M. and Ziebuhr, J. (2013) Middle East Respiratory Syndrome Coronavirus (MERSCoV): Announcement of the Coronavirus Study Group. Journal of Virology, 87, 7790-7792. http://dx.doi.org/10.1128/JVI.01244-13

[4] van Boheemen, S., De Graaf, M., Lauber, C., Bestebroer, T.M., Raj, V.S., Zaki, A.M., Osterhaus, A.D., Haagmans, B.L., Gorbalenya, A.E., Snijder, E.J. and Fouchier, R.A. (2012) Genomic Characterization of a Newly Discovered Coronavirus Associated with Acute Respiratory Distress Syndrome in Humans. mBio, 3, e00473-12. http://dx.doi.org/10.1128/mBio.00473-12

[5] Cotton, M., Lam, T.T., Watson, S.J., Palser, A.L., Petrova, V., Grant, P., Pybus, O.G., Rambaut, A., Guan, Y., Pillay, D., Kellam, P. and Nastouli, E. (2013) Full-Genome Deep Sequencing and Phylogenetic Analysis of Novel Human Betacoronavirus. Emerging Infectious Diseases, 19, 736-742. http://dx.doi.org/10.3201/eid1905.130057

[6] Raj, V.S., Mou, H., Smits, S.L., Dekkers, D.H., Muller, M.A., Dijkman, R., Muth, D., Demmers, J.A., Zaki, A., Fouchier, R.A., Thiel, V., Drosten, C., Rottier, P.J., Osterhaus, A.D., Bosch, B.J. and Haagmans, B.L. (2013) Dipeptidyl Peptidase 4 Is a Functional Receptor for the Emerging Human Coronavirus-EMC. Nature, 495, 251-254. http://dx.doi.org/10.1038/nature12005

[7] Lu, G., Hu, Y., Wang, Q., Qi, J., Gao, F., Li, Y., Zhang, Y., Zhang, W., Yuan, Y., Bao, J., Zhang, B., Shi, Y., Yan, J. and Gao, G.F. (2013) Molecular Basis of Binding between Novel Human Coronavirus MERS-CoV and Its Receptor CD26. Nature, 500, 227-231. http://dx.doi.org/10.1038/nature12328

[8] CDC (2014) First Case of Middle East Respiratory Syndrome Coronavirus Infection (MERS) in the United States. http://www.cdc.gov/media/releases/2014b/p0502-US-MERS.html

[9] CDC (2014) Interim Guidelines for Collecting, Handling, and Testing Clinical Specimens from Patients under Investigation (PUIs) for Middle East Respiratory Syndrome Coronavirus (MERS-CoV). Version 2.1. http://www.cdc.gov/coronavirus/mers/guidelines-clinical-specimens.html

[10] Corman, V.M., Eckerle, I., Bleicker, T., Zaki, A., Landt, O., Eschbach-Bludau, M., van Boheemen, S., Gopal, R., Ballhause, M., Bestebroer, T., Muth, D., Muller, M., Drexler, J., Zambon, M., Osterhaus, A., Fouchier, R. and Drosten, C. (2012) Detection of a Novel Human Coronavirus by Real-Time Reverse-Transcription Polymerase Chain Reaction. Eurosurveillance, 17, 20285.

[11] CDC (2014) Laboratory Testing for Middle East Respiratory Syndrome Coronavirus (MERS-CoV). http://www.cdc.gov/coronavirus/mers/lab/lab-testing.html

[12] Chen, Y., Chan, K., Kang, Y., Chen, H., Luk, H.K., Poon, R.S., Chan, J.F., Yuen, K., Xia, N., Lau, S.K. and Woo, P.C. (2015) A Sensitive and Specific Antigen Detection Assay for Middle East Respiratory Syndrome Coronavirus. Emerging Microbes and Infections, 4, e26. http://dx.doi.org/10.1038/emi.2015.26

[13] World Health Organization (2014) WHO Risk Assessment. Middle East Respiratory Syndrome Coronavirus (MERSCoV). http://www.who.int/csr/disease/coronavirus_infections/MERS_CoV_RA_20140424.pdf?ua=1

[14] Tina, H.S. (2013) Story One: Scientists Race to Understand Deadly New Virus: SARS-Like Infection Causes Severe Illness, but May Not Spread Quickly among People. Science News, 183, 5-6. http://dx.doi.org/10.1002/scin.5591830603

[15] Zaki, A.M., van Boheemen, S., Bestebroer, T.M., Osterhaus, A.D. and Fouchier, R.A. (2012) Isolation of a Novel Coronavirus from a Man with Pneumonia in Saudi Arabia. The New England Journal of Medicine, 367, 1814-1820. http://dx.doi.org/10.1056/NEJMoa1211721

[16] Raj, S.V., Elmoubasher, A.B., Farag, A., Chantal, B.E., Reusken, C.B., Mart, M., Pas, S.D., Voermans, J., Smits, S.L., Albert, D.M., Osterhaus, A., Al-Mawlawi, N., Al Romaihi, H.E., AlHajri, M.M., El-Sayed, A.H., Khaled, A., Ghobashy, H., Alhajri, F., Al-Thani, M., Al-Marri, S.A., El-Maghraby, M.M., Marion, P.G., Koopmans, M.P. and Haagmans, B.L. (2014) Isolation of MERS Coronavirus from Dromedary Camel, Qatar, 2014. Emerging Infectious Diseases, 20, 1339-1342. http://dx.doi.org/10.3201/eid2008.140663

[17] Rha, B., Rudd, J., Feikin, D., Watson, J., Curns, A.T., Swerdlow, D.L., Pallansch, M.A. and Gerber, S.I. (2015) Update on the Epidemiology of Middle East Respiratory Syndrome Coronavirus (MERS-CoV) Infection, and Guidance for the Public, Clinicians, and Public Health Authorities. CDC Morbidity and Mortality Weekly Report, 64, 61-62.

[18] World Health Organization (2015) Middle East Respiratory Syndrome Coronavirus (MERS-CoV): Summary of Current Situation, Literature Update and Risk Assessment-As of 5 February 2015. http://www.who.int/csr/disease/coronavirus_infections/mers-5-february-2015.pdf?ua=1

[19] Mackay, M.I. and Arden, E.K. (2015) Middle East Respiratory Syndrome: An Emerging Coronavirus Infection Tracked by the Crowd. Virus Research, 202, 60-88. http://dx.doi.org/10.1016/j.virusres.2015.01.021 
[20] Azhar, E.I., Hashem, A.M., El-Kafrawy, S.A., Sohrab, S.S., Aburizaiza, A.S., Farraj, S.A., Hassan, A.M., Al-Saeed, M.S., Jamjoom, G.A. and Madani, T.A. (2014) Detection of the Middle East Respiratory Syndrome Coronavirus Genome in an Air Sample Originating from a Camel Barn Owned by an Infected Patient. mBio, 5, e01450-14. http://dx.doi.org/10.1128/mbio.01450-14

[21] Alagaili, A.N., Briese, T., Mishra, N., Kapoor, V., Sameroff, S.C., De Wit, E., Munster, V.J., Hensley, L.E., Zalmout, I.S., Kapoor, A., Epstein, J.H., Karesh, W.B., Daszak, P., Mohammed, O.B. and Lipkin, W.I. (2014) Middle East Respiratory Syndrome Coronavirus Infection in Dromedary Camels in Saudi Arabia. mBio, 5, e01002-14. http://dx.doi.org/10.1128/mBio.01002-14

[22] Reusken, C.B., Messadi, L., Feyisa, A., Ularamu, H., Godeke, G.J., Danmarwa, A., Dawo, F., Jemli, M., Melaku, S., Shamaki, D., Woma, Y., Wungak, Y., Gebremedhin, E.Z., Zutt, I., Bosch, B.J., Haagmans, B.L. and Koopmans, M.P. (2014) Geographic Distribution of MERS Coronavirus among Dromedary Camels, Africa. Emerging Infectious Diseases, 20, 1370-1374. http://dx.doi.org/10.3201/eid2008.140590

[23] Corman, V.M., Jores, J., Meyer, B., Younan, M., Liljander, A., Said, M.Y., Gluecks, I., Lattwein, E., Bosch, B., Drexler, J., Bornstein, S., Drosten, C. and Muller, M.A. (2014) Antibodies against MERS Coronavirus in Dromedary Camels, Kenya, 1992-2013. Emerging Infectious Diseases, 20, 1319-1322. http://dx.doi.org/10.3201/eid2008.140596

[24] Memish, Z.A., Mishra, N., Olival, K.J., Fagbo, S.F., Kapoor, V., Epstein, J.H., AlHakeem, R., Durosinloun, A., Al Asmari, M., Islam, A., Kapoor, A., Briese, T., Daszak, P., Al Rabeeah, A.A. and Lipkin, W.I. (2013) Middle East Respiratory Syndrome Coronavirus in Bats, Saudi Arabia. Emerging Infectious Diseases, 19, 1819-1823. http://dx.doi.org/10.3201/eid1911.131172

[25] Reusken, C.B., Haagmans, B.L., Muller, M.A., Gutierrez, C., Godeke, G.J., Meyer, B., Muth, D., Raj, V.S., Smits-De Vries, L., Corman, V.M., Drexler, J.F., Smits, S.L., El Tahir, Y.E., De Sousa, R., Van Beek, J., Nowotny, N., Van Maanen, K., Hidalgo-Hermoso, E., Bosch, B.J., Rottier, P., Osterhaus, A., Gortázar-Schmidt, C., Drosten, C. and Koopmans, M.P. (2013) Middle East Respiratory Syndrome Coronavirus Neutralising Serum Antibodies in Dromedary Camels: A Comparative Serological Study. The Lancet Infectious Diseases, 13, 859-866. http://dx.doi.org/10.1016/S1473-3099(13)70164-6

[26] CDC (2013) Health Alert Network. Notice to Health Care Providers: Updated Guidelines for Evaluation of Severe Respiratory Illness Associated with Middle East Respiratory Syndrome Coronavirus (MERS-CoV). http://emergency.cdc.gov/HAN/han00348.asp

[27] World Health Organization (2014) Middle East Respiratory Syndrome Coronavirus (MERS-CoV). Summary and Literature Update-As of 9 May 2014. http://www.who.int/csr/disease/coronavirus infections/MERS CoV Update 09 May 2014.pdf?ua=1

[28] Guery, B., Poissy, J., Mansouf, L., Sejourne, C., Ettahar, N., Lemaire, X., Vuotto, F., Goffard, A., Behillil, S., Enouf, V., Caro, V., Mailles, A., Che, D., Manuguerra, J.C., Mathieu, D., Fontanet, A. and Van der Werf, S. (2013) Clinical Features and Viral Diagnosis of Two Cases of Infection with Middle East Respiratory Syndrome Coronavirus: A Report of Nosocomial Transmission. Lancet, 381, 2265-2272. http://dx.doi.org/10.1016/S0140-6736(13)60982-4

[29] Assiri, A., McGeer, A., Perl, T.M., Price, C.S., Al Rabeeah, A.A., Cummings, D.A., Alabdullatif, Z.N., Assad, M., Almulhim, A., Makhdoom, H., Madani, H., Alhakeem, R., Al-Tawfiq, J.A., Cotton, M., Watson, S.J., Kellam, P., Zumla, A.I. and Memish, Z.A. (2013) Hospital Outbreak of Middle East Respiratory Syndrome Coronavirus. The New England Journal of Medicine, 369, 407-416. http://dx.doi.org/10.1056/NEJMoa1306742

[30] Wikipedia (2015) Middle East Respiratory Syndrome. http://en.wikipedia/wiki/File:Symptoms-of-MERS-raster.png

[31] Almazan, F., Marta, L., Diego, D., Sola, I., Zuñiga, S.A., Jose, L., Torres, N., Marquez-Jurado, S., Andrés, G. and Enjuanes, L. (2013) Engineering a Replication-Competent, Propagation-Defective Middle East Respiratory Syndrome Coronavirus as a Vaccine Candidate. mBio, 4, e00650-13. http://dx.doi.org/10.1128/mBio.00650-13

[32] De Wilde, A.H., Raj, V.S., Oudshoorn, D., Bestebroer, T.M., Van Nieuwkoop, S., Limpens, R.W., Posthuma, C.C., Van der Meer, Y., Barcena, M., Haagmans, B.L., Snijder, E.J. and Van den Hoogen, B.G. (2013) MERS-Coronavirus Replication Induces Severe in Vitro Cytopathology and Is Strongly Inhibited by Cyclosporin A or Interferon-Alpha Treatment. Journal of General Virology, 94, 1749-1760. http://dx.doi.org/10.1099/vir.0.052910-0

[33] Danielsson, N. and Catchpole, M. (2012) Novel Coronavirus Associated with Severe Respiratory Disease: Case Definition and Public Health Measures. Eurosurveillance, 17, pii 20282.

[34] Kilianski, A., Mielech, A.M., Deng, X. and Baker, S.C. (2013) Assessing Activity Andinhibition of Middle East Respiratory Syndrome Coronavirus Papain-Like and 3C-Like Proteases Using Luciferase-Based Biosensors. Journal of Virology, 87, 11955-11962. http://dx.doi.org/10.1128/JVI.02105-13

[35] Graham, R.L., Donaldson, E.F. and Baric, R.S. (2013) A Decade after SARS: Strategies for Controlling Emerging Coronaviruses. Nature Reviews Microbiology, 11, 836-848.

[36] Corman, V.M., Muller, M.A., Costabel, U., Timm, J., Binger, T., Meyer, B., Kreher, P., Lattwein, E., Eschbach-Bludau, M., Nitsche, A., Bleicker, T., Landt, O., Schweiger, B., Drexler, J.F., Osterhaus, A.D., Haagmans, B.L., Dittmer, U., 
Bonin, F., Wolff, T. and Drosten, C. (2012) Assays for Laboratory Confirmation of Novel Human Coronavirus (hCoVEMC) Infections. Eurosurveillance, 17, pii 20334.

[37] World Health Organization (2013) Laboratory Testing for Middle East Respiratory Syndrome Coronavirus. http://www.who.int/csr/disease/coronavirus_infections/MERS_Lab_recos_16_Sept_2013.pdf

[38] Azhar, E.I., El-Kafrawy, S.A., Farraj, S.A., Hassan, A.M., Al-Saeed, M.S., Hashem, A.M. and Madani, T.A. (2014) Evidence for Camel-to-Human Transmission of MERS Coronavirus. The New England Journal of Medicine, 370, 2499-2505. http://dx.doi.org/10.1056/NEJMoa1401505

[39] European Centre for Disease Prevention and Control (ECDC) (2013) Severe Respiratory Disease Associated with a Novel Coronavirus. Rapid Risk Assesment. ECDC, Stockholm. http://ecdc.europa.eu/en/publications/Publications/novel-coronavirus-rapid-risk-assessment-update.pdf

[40] Al-Tawfiq, J.A. and Memish, Z.A. (2014) What Are Our Pharmacotherapeutic Options for MERS-CoV? Expert Review of Clinical Pharmacology, 7, 235-238. http://dx.doi.org/10.1586/17512433.2014.890515

[41] Pascal, K.E., Coleman, C.M., Mujica, A.O., Kamat, V., Badithe, A., Fairhurst, J., Hunt, C., Strein, J., Berrebi, A., Sisk, J.M., Matthews, K.L., Babb, R., Chen, G., Lai, K.V., Huang, T.T., Olson, W., Yancopoulos, G.D., Stahl, N., Frieman, M.B. and Kyratsous, C.A. (2015) Pre- and Postexposure Efficacy of Fully Human Antibodies against Spike Protein in a Novel Humanized Mouse Model of MERS-CoV Infection. Proceedings of the National Academy of Sciences of the United States of America, 112, 8738-8743. www.pnas.org/cgi/doi/10.1073/pnas.1510830112

[42] World Health Organization (2014) Middle East Respiratory Syndrome Coronavirus (MERS-CoV). Update on MERSCoV Transmission from Animals to Humans, and Interim Recommendations for at Risk Groups. http://www.who.int/csr/disease/coronavirus_infections/MERS_CoV_RA_20140613.pdf?ua=1

\section{List of Abbreviations}

CD26: Cluster of Differentiation 26

CDC: Centers for Disease Control and Prevention

cDNA: Complementary Deoxyribonucleic Acid

CPE: Cytopathic Effect

DPP4: Dipeptidyl Peptidase-4

ECDC: European Centre for Disease Prevention and Control

hCoV: Human Coronaviruses

Huh7: Human Hepatocellular Carcinoma Cell Line 7

ICTV: International Committee on Taxonomy of Viruses

MERS: Middle East Respiratory Syndrome

MERS-CoV: Middle East Respiratory Syndrome-Coronavirus

ORF: Open Reading Frame

RdRp: RNA-Dependent RNA Polymerase

RNA: Ribonucleic Acid

RT-rtPCR: Real Time Reverse Transcription Polymerase Chain Reaction

SARS: Severe Acute Respiratory Syndrome

SDS-PAGE: Sodium Dodecyl Sulfate Polyacrylamide Gel Electrophoresis

WHO: World Health Organization 